\title{
Repeated freezing and thawing of peripheral blood and DNA in suspension: effects on DNA yield and integrity
}

\author{
Kenneth S Ross, Neva E Haites, Kevin F Kelly
}

\begin{abstract}
The possibility of DNA degradation is of concern to all involved in the storage of DNA, whether for diagnostic or research purposes. Many DNA banks are at present maintained at low temperatures, but optimum conditions for storage and handling have yet to be fully assessed. Both DNA and fresh blood have been subjected to repeated cycles of freezing and thawing and DNA extracted from the blood. DNA yield has been established and integrity examined by digestion, electrophoresis, and Southern blot analysis using DNA fingerprinting techniques. No degradation of DNA could be detected using these techniques; however, DNA yield was shown to be adversely affected by freezing, with yield reduced by more than $25 \%$ in blood samples frozen only once.
\end{abstract}

Research projects in medical genetics frequently require the accumulation of DNA samples over an extended period of time, with analysis performed at the end of the gathering period, when a series is complete. An area of potential concern, when considering results obtained from experiments involving such samples, is the possibility of DNA degradation in storage.

Many diagnostic and research laboratories also routinely maintain extensive DNA banks, often containing samples of great importance. The question of DNA stability in storage is therefore of considerable significance, especially when the DNA is stored for diagnostic purposes. In the recently published report of the Clinical Genetics Society working party

Department of Medicine and Therapeutics, University of Aberdeen, Aberdeen.

K S Ross

Department of Molecular and Cell Biology, University of Aberdeen, Medical School Buildings, Foresterhill, Aberdeen AB9 2ZD.

N E Haites, K F Kelly

Correspondence to Dr Haites.

Received for publication 23 January 1990.

Revised version accepted for publication 30 March 1990. on DNA banking, Yates et $a l^{1}$ warned against repeated freezing and thawing of blood since this may prejudice subsequent DNA yield and integrity. However, little published information is available with regard to the extent of this damage or the form it may take. In order to investigate this matter experimentally, we have subjected both DNA and fresh blood to repeated freezing/thawing cycles. DNA yield was determined, and DNA fingerprinting techniques applied in an attempt to visualise altered restriction profiles.

\section{Methods}

Blood from five normal subjects was collected with $\mathrm{K}^{+}$EDTA as anticoagulant. Five aliquots from each were immediately frozen, and DNA extracted from a further one by standard methods. ${ }^{2}$ This DNA was resuspended in TE buffer and divided into six aliquots. One was stored at $+4^{\circ} \mathrm{C}$, one at $-70^{\circ} \mathrm{C}$, and the remaining four subjected to $5,10,20$, and 40 cycles of freezing and thawing respectively. Of the five aliquots of fresh blood frozen immediately after collection, one remained frozen while the other four were subjected to the same cycles as the extracted DNA. Freezing was achieved in a dry ice/ethanol bath followed by thawing at $+37^{\circ} \mathrm{C}$. On completion of the freeze/thaw series, DNA was extracted from the blood samples and resuspended in TE buffer. Assays for yield were carried out using absorbance at $260 \mathrm{~nm}$, and confirmed chemically by the DAPI-fluorescence method. ${ }^{3}$ DNA $(5 \mu \mathrm{g})$ from each sample was digested with $H$ inf $I$ and fingerprinting performed by established methods, using the multilocus minisatellite probe $33 \cdot 6 .^{4}$

\section{Results}

DNA yield was determined after resuspension, and the results are shown in the table.

Examination of autoradiographs showing the fingerprint patterns showed a consistent band pattern on all samples, regardless of predigestion treatment (figure). The variation in intensity in band 14, lane 1 probably arises from the use of intensifying screens in the autoradiograph cassette. ${ }^{5}$ 
Effect of repeated freezing and thawing on DNA yield.

\begin{tabular}{|c|c|c|c|c|c|c|}
\hline & \multicolumn{6}{|c|}{ No of freeze/thaw cycles } \\
\hline & 0 & 1 & 5 & 10 & 20 & 40 \\
\hline $\begin{array}{l}\text { Mean yield ( } \mu \text { DNA } \\
\text { per ml of blood) } \\
\text { SD } \\
\text { Percentage yield } \\
\text { (expressed as } \\
\text { percentage of } \\
\text { yield from } \\
\text { fresh blood) }\end{array}$ & $\begin{array}{r}37 \cdot 6 \\
5 \cdot 7\end{array}$ & $\begin{array}{r}28 \cdot 1 \\
5.4\end{array}$ & $\begin{array}{r}30.6 \\
5.7\end{array}$ & $\begin{array}{r}26.4 \\
4.7\end{array}$ & $\begin{array}{r}23 \cdot 9 \\
3 \cdot 4\end{array}$ & $\begin{array}{r}26 \cdot 6 \\
5.4\end{array}$ \\
\hline
\end{tabular}

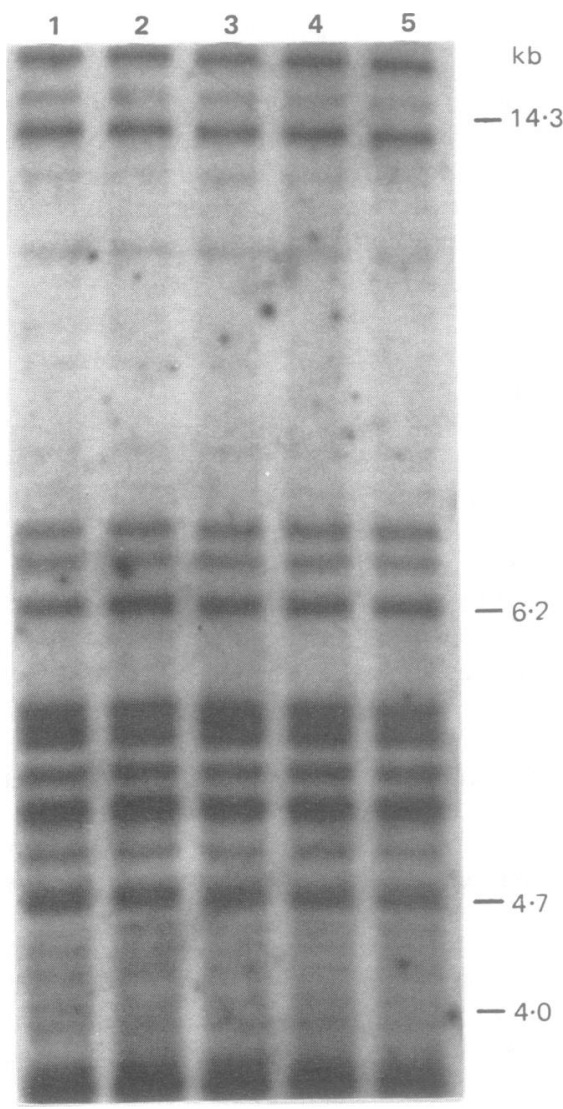

DNA fingerprints produced from DNA extracted from blood subjected to repeated freezel thaw cycles. Lane 1: fresh. Lanes 2 to 5: blood subjected to 5, 10,20, and 40 cycles of freezing and thawing before extraction of DNA.

\section{Discussion}

A difference of about $25 \%$ was noted in the DNA yield between a fresh sample and one extracted after freezing at $-70^{\circ} \mathrm{C}$. This is the only cycle to show an effect on DNA yield. Deviation in the results from further cycles is too great to comment on the trend.
Quality of DNA recovered, as determined by OD $\frac{260}{280}$, did not appear to be affected by freezing and thawing, and the appearance of the lanes on the gel, when stained with ethidium bromide and viewed under ultraviolet light, was consistent with well digested, high molecular weight DNA. DNA fingerprinting offers a method of examining many loci simultaneously, and thus the possibility of assessing DNA damage. Widespread, non-specific damage to DNA may appear on autoradiography as reduced band sharpness or smearing or, in the case of site specific damage, shifts in molecular weight or the gain/loss of individual bands. Examination of the fingerprints produced from both blood and DNA subjected to repeated freezing and thawing indicated stability of pattern with no change in the number of bands evident after 40 freeze/thaw cycles. Intensity changes may be seen with autoradiography performed in the presence of intensifying screens. ${ }^{5}$

Similar stability of band pattern to that seen in this study has been observed when DNA stored for 12 months at $+4^{\circ} \mathrm{C}$ in TE buffer was compared with fresh DNA from the same control. In another experiment, two unrelated samples of human DNA were mixed in varying ratios. Bands could be visualised when the DNA from which they derived represented as little as $2 \%$ of the total DNA, suggesting that if freezing and thawing of DNA does produce site specific damage leading to altered RFLP patterns, at least $2 \%$ of such susceptible sites would have to be affected before a change could be visualised by DNA fingerprinting.

It appears that repeated freezing and thawing of DNA, whether in purified form or as blood, does not degrade the DNA in such a way as to affect the restriction pattern producing a DNA fingerprint.

However, DNA yield from blood has been shown to fall by more than $25 \%$ even after one freezing at $-70^{\circ} \mathrm{C}$, and for this reason it is suggested that, whenever possible, and especially for very important samples, the DNA should be extracted from fresh blood as soon as possible after collection.

The work is supported by a grant from the University Development Trust, Milne Bequest.

1 Yates JRW, Malcolm S, Read AP. Guidelines for DNA banking report of the Clinical Genetics Society working party on DNA banking. $\mathcal{F}$ Med Genet 1989;26:245-50.

2 Kunkel LM, Smith KD, Boyer SH, et al. Analysis of human Ychromosome-specific reiterated DNA in chromosome variants. Proc Natl Acad Sci USA 1977;74:1245-9.

3 Kapuscinski J, Skoczylas B. Simple and rapid fluorimetric method for DNA microassay. Anal Biochem 1977;83:252-7.

4 Jeffreys AJ, Wilson V, Thein SL, et al. DNA "fingerprints" and segregation analysis of multiple markers in human pedigrees. Am ₹ Hum Genet 1986;39:11-24.

5 Ridge SA, Worwood M. Letters to the editor. Comments on 'Differences in DNA-fingerprints between remission and relapse in childhood acute lymphoblastic leukaemia'. Leuk Res 1989;13:511-2. 